\title{
Impact of Foreign Direct Investment on Employment Evidence: Zanzibar Tourism Industry
}

\author{
Ali Othman Abbas, Zhang Xifeng \\ School of Accounting, Jiangxi University of Finance and Economics, Nanchang, China \\ Email address: \\ abbasal14@hotmail.com (A. O. Abbas), zhangxifeng@jxufe.edu.cn (Zhang Xifeng)
}

To cite this article:

Ali Othman Abbas, Zhang Xifeng. Impact of Foreign Direct Investment on Employment Evidence: Zanzibar Tourism Industry. International Journal of Economics, Finance and Management Sciences. Vol. 4, No. 5, 2016, pp. 250-256. doi: 10.11648/j.ijefm.20160405.13

Received: August 20, 2016; Accepted: September 5, 2016; Published: September 6, 2016

\begin{abstract}
With the advent of globalization, there has been a massive surge of Foreign Direct Investment (FDI) inflows into developing countries during the past two decades. Tourism as one of the currently fast growing industries across the world is one of the few service sectors showing concrete and quantitative trading opportunities for all countries, regardless of their level of development. The objective of the study was to assess the impacts that FDI has, is having, and will have on the well-being and performance of the Zanzibar labour market. The data were collected by the use of questionnaire and interview and analysis were drawn from the tourist investors in particular those in northern and eastern coasts, and Zanzibar Stone Town. The study revealed that there are positive impacts of the foreign direct investment on employment in Zanzibar, as well as positive relationship between direct foreign investment and tourism. We recommend promoting tourism abroad, balancing of tourism and other economic sectors attracting FDI in other sectors of the economy.
\end{abstract}

Keywords: Foreign Direct Investment, Employment, Tourism

\section{Introduction}

One of the sensitive and important areas for economic growth of developing countries is foreign direct investment (FDI). According to [1], FDI is not only a simple transfer of money, but also a mixture of financial and intangible assets such as technologies, managerial capabilities, marketing skills and other assets. Notwithstanding, the major debate in the literatures regarding the impact of FDI on economic growth, is the Zanzibar Government's goal to attract FDIs to help boost its domestic saving rate accompanied by inefficient financial intermediation which hinders Zanzibar's strategies to finance growth. The other motive behind such attempts is the opportunity to benefit from the direct and indirect effects of FDIs on increasing demand for labour. This is especially important given a chronic unemployment problem that the economy suffers, despite the enabling environment that helps Zanzibar emerge as a competing tourist destination in East African region. The traditional argument states that an inflow of FDI improves economic growth and thereby enhances employment opportunities. In their study [5] have shown that FDI's social and distributional impact on the host country has been generally favorable in developing countries of various regions. Apart from bringing in a package of highly productive resources into the host economy, there have been visible positive impacts on job creation not only in those sectors attracting FDI inflows but also in the supportive domestic industries. It is believed that reduction of poverty requires a continuous economic growth [4], however it has been widely recognized that growth alone is not sufficient; the most needed is economic growth that is purposely targeted to benefit local poor people. Tourism industry has been recognized as a proper tool for enhancing pro poor growth, has also been said to attract a big number of FDIs in many poor countries. [28], identifies clearly that tourism is a fundamental pillar for its economic growth. During 2007, Zanzibar recorded 623.4 million US Dollar as FDI inflow in tourism industry [28]. Thus any abnormality in the tourism sector will disturb the economic growth and development of poor communities. Since the growth of FDI affects the economies of most tourists generating countries such as the (United Kingdom, the United States and Germany), it is likely that Zanzibar, which is heavily dependent on international visitors, has experienced a severe impact on its tourism industry. Tourism industry which is highly occupied by foreigners, including 
investors, as well as visitors, has been publicized as potentially powerful enabling tool for business and growth performance. However, it is not clear what percentage of tourism expenditure remains in the host country and host communities. According to [27], out of US\$ 100 spent by tourists in the fewer developing countries, only five dollars remain to the local communities.

Generally, when used appropriately, FDI is said to help enhance economic growth indirectly where the direct transfer of technology augments the stock of knowledge in the recipient country through labour training and skill acquisition, new management practices and organizational arrangements. FDI is also an important vehicle for contributing relatively more to growth than domestic investment. There is therefore a need to find how to understand the way FDI contributes to tourism in Zanzibar labour market, focusing on understanding the challenges facing the tourism FDI in Zanzibar towards its contribution to economic growth. Also there is a need to understand the influence that tourism FDI has to the development of Zanzibar society. The existence of globalization has enabled Zanzibar to attract many FDIs particularly in tourism sector. The motivation that forces Zanzibar to react on such globalization through attracting FDIs was the opportunity to benefit from the direct and indirect effects of FDIs on increasing demand for labour.

\section{Literature Review}

According to [9], FDI is positively related to employment creation that will improve competitiveness and, thus, create employment and increase the welfare of the host nation. $\mathrm{He}$ adds that if FDI is concentrated in labour-intensive industries, the increase will be substantial. The author explains that, FDI can also lead to increased employment amongst local firms as a result of backward or forward linkage so that the direct employment by foreign affiliates may underestimate the total impact. There could also be spillovers to domestic firms as a result of training by foreign investors or technology transfer. Foreign firms that are subject to pressures in their home countries may also bring with them higher labour standards and wages than the norm for the host economy. Where a firm makes a long-term commitment, it can provide stable employment. It was also suggested that; attracting foreign firms to relatively underdeveloped countries can provide a direct impact on employment and capital creation and in turn, potential indirect effects via spillovers to local firms [13]. [8], provides a result which positively favors the relationship between the two variables. He reports a positive correlation ratio for employment and lagged values of FDI (percentage of GDP). The study also argues that a large proportion of the Caribbean labour force, for example, is employed in FDI enterprises and the ratio of employment in FDI enterprises to total employment showed an inclining movement over a decade. The result goes further that in all Caribbean countries except Saint Kitts, Nevis, and Suriname, there was a positive relationship between employment and FDI. [21], asserts that in general, FDI inflows to developing countries have had positive effects on economic growth, job creation, and living standards of workers. In a similar study conducted in China, [23] finds that FDI has significantly promoted economic growth by contributing to domestic capital formation, increasing exports, and creating new employment. There has been a noticeable creation of jobs not only in those sectors attracting FDI inflows but also in the supportive domestic industries. Another series of studies support a positive relationship between FDI and employment. [14], for example, reports that FDI is positively affecting the employment growth in foreign-owned firms largely due to their firm characteristics and high survival rates. Similar effects were recorded in privately owned domestic firms as well, possibly due to spillovers. The positive impact of FDI was also evident in the Irish economy. She attracted large FDI inflows into the export-oriented-foreign firms in the 1990 s and $63 \%$ of manufacturing employment was provided by these multinational corporations (MNCs) $[7,11]$ report a positive relationship between employment and FDI. The authors found that more than $80 \%$ of net job creation of the corporate sector between 1993 and 2000 can be attributed to foreign companies; the result which reflected large FDI inflows during the period. However, the authors also point out that between 2000 and 2002, employment in foreign firms decreased with the shift of FDI from low-value added sectors to medium-tech sectors. [18] investigated and found out that a key channel of the impact of FDI on development is through its effects on domestic factor markets, especially domestic investment and employment. In this context, they analyzed the two-way linkage between FDI and domestic investment in Sub-Saharan Africa. Their results suggested that firstly, FDI crowds in domestic investment, and secondly, countries will gain much from measures aimed at improving the domestic investment climate.

On the other hand, [6] analyzed the effects of FDI inflows on local employment in manufacturing across a sample of states in the United States for the period of 1974-1994. They found that the effects change from one industry to another. While FDI inflows have positive employment effects for a subgroup of industries such as printing and publishing and transportation equipment \& instruments, negative effects have been found for another subgroup of industries such as leather and stone, clay and glass. [19] also found the employment effect of FDI inflows to manufacturing industry in Central and Eastern European countries as insignificant, if not negative. [10] assessed the link between FDI and employment for Argentina, Brazil and Mexico and found that the impact of FDI on employment was fairly positive in Mexico and Argentina, but disappointing in Brazil. However, in this regard, the relatively positive figures were overestimated, as the figures were for the whole sector and included informal workers whose share increased in Brazil and Mexico. The growth rate of employment was very low, but slightly positive, despite major rationalization measures with regard to production and personnel: in Argentina 
(1.9\%), Mexico (1.0\%, but below average) and Brazil $(0.3 \%)$. The above-average labour intensity of this category may have contributed to this favorable result. New data from firm surveys in Kenya, Tanzania and Uganda suggest that there are important positive effects from FDI for both the host economies and the workers in foreign-owned firms [28]. In Turkey, studies also show contradicting findings. [17], reports that there is no causality between FDI inflows and employment for the period of 1970-2005. His analysis, however, was criticized to have showed some shortcomings, such as, the study covers a long period of time in which there were major structural breaks in the amount of FDI inflows. Furthermore, he used aggregated data disregarding any sectoral consideration. The descriptive study by [15], on the other hand, compares the performance of FDI firms on some aggregates including employment, wages, labor productivity and share of wages in value added in comparison with domestic firms during 1992-2001 period. They found that FDI firms fare slightly better in terms of employment creation than domestic firms. However, they also noted the disappointing performance of FDI in comparison with the expectations it raised in the first place. It was also suggested that FDI inflows negatively affected employment in Turkey as the majority of FDI inflows took the form of Merger and Acquisitions rather than Greenfield Investment. However, the study also suffers from the same drawbacks as pointed out by [17]. The above findings suggest that it is possible to identify circumstances under which FDI has a significant positive impact on employment. Where such investment supplements domestic investment and involves the creation of new "Greenfield" plants, demand for labour will tend to increase. The findings were echoed by [16], in an assessment of Employment Effect of FDI inflows in Egypt. The result of the assessment suggests that where aggregate FDI had an insignificant effect on the demand for labour, except when it interacted with the size of the technology gap, then aggregate FDI had a negative effect impact on the demand for labour. Greenfield and manufacturing FDI showed a positive effect when they interacted with the level of human capital and exports, while Merger and Acquisitions, agriculture and services FDI had negative direct effect and insignificant interactive effects. Specifically, limited studies relate the impact of tourism industry on employment. For instance, the study conducted in Vietnam suggests that tourism industry may have positive impact on new jobs creation. Furthermore, it was explained that, the industry can create jobs in two ways [2], [12] namely, first tourism can create jobs immediately through employing local citizens in hotels, restaurants, and entertainment and tourist services that cater directly to tourists. Second, tourism can create jobs through multiplier effects. For example, by creating demand for local products supplied to establishments that would not have existed without tourists, tourism can create employment in related service industries; tourism also can create jobs to serve the additional demand from otherwise-unemployed, local citizens working in the industry. As can be seen, it is not possible to draw any concrete conclusion from the existing literature on the relationship between FDI and employment in Zanzibar. The main reason for the inconsistent findings can be attributed to the different time periods and sectors that are covered by these works. For a solid analysis of FDI inflows on Zanzibar employment level, there is a need for the consideration of the tourism sector which leads the Zanzibar economy by attracting many foreign investors.

\section{Methodology}

In order to achieve the objectives of this study the research used survey method. Self-completion questionnaires with open and closed questions were developed. The questionnaires were distributed to a total of one hundred (100) respondents, a sample which included randomly selected tour operators and hotel investments. According to the Zanzibar Commission for Tourism, the registered tourism businesses in Zanzibar is about 250, thus, 100 respondents is more than thirty percent as recommended by [22]. Also the interview was conducted with 4 experienced government officials. The SPSS software were used for data analysis.

\section{Results and Discussion}

\subsection{Foreign Direct Investment in Tourism}

In today's business world, there is no single stakeholder in doubt of the advantage that tourists demand can have to the development of tourism industry.

Table 1. Correlation between Tourism and Foreign Direct Investment.

\begin{tabular}{llll}
\hline & & Tourism & Foreign Direct Investment \\
\hline \multirow{3}{*}{ Tourism } & Pearson Correlation & 1 & $.375^{* *}$ \\
& Sig. (2-tailed) & & .002 \\
& $\mathrm{~N}$ & 63 & 63 \\
\multirow{3}{*}{ Foreign Direct Investment } & Pearson Correlation & $.375^{* *}$ & 1 \\
& Sig. (2-tailed) & .002 & 63 \\
\hline
\end{tabular}

**. Correlation is significant at 0.01 level (2-tailed).

The table 1 above presents positive correlation between FDI and tourism, at $37.5 \%$. Statistically, correlation coefficient is significant at $\mathrm{P}<0.01$. This implies that whenever there is an increase in the number of tourists arrival, more FDIs are attracted in the country. The result also reflects the fact that a high share of investment is in tourism which to a large extent involves foreign capital. The Zanzibar Investment policy followed avidly by the ZIPA has resulted 
in a tilt towards a significant level of FDI in tourism, though, more effort is still needed to be put in place by the authority to attract more FDIs for a better level of government revenue collection and development of the society. However, it needs to be borne in mind that if new FDIs based companies capture market share from local established firms, there is a danger that jobs created by such firms may be gained at the expense of jobs lost in the local companies. The tourism sector with a possession of higher share of FDI in Zanzibar by accounting for $65.8 \%$ of the total projects was approved during the period. The remaining $34.2 \%$ is shared among the rest whereby wholesale and retail trade and manufacturing accounted for $68.7 \%$ and $7.3 \%$ respectively. The least share of FDI market was $1.4 \%$ recorded for education sector. The result of our study is also supported by [3]. Using data from the United Nations (UN) and Asian Pacific Economic Cooperation (APEC), [3] demonstrated that the stock of world FDI is spread across all sectors, with about 40 per cent invested in the services sector. Notwithstanding the wideranging FDI-services and extensive trade-and-services linkages, there is relatively little empirical work examining the possible relationships between FDI and services trade. Not only is demonstrated in services trades like tourism, the causal relationships between FDI and commodity trade have been studied and documented extensively. For example, [3] in his study conducted in Mexico found causal relationships between inward FDI and exports are running both ways. [26] confirmed for Malaysia the existence of bi-directional causality between inward FDI and semiconductor exports. Furthermore, [20] made a novel attempt to study the interactions among inward FDI, exports and imports, and found evidence of long-run bi-directional causality between FDI and exports as well as imports in the case of Mexico. Because of its islands nature, fishing and seaweeds farming are among important industries that provide employment to many people in Zanzibar. This means that Zanzibar can also benefit from FDI engaged in commodity trade such as manufacturing, fishing and seaweeds companies; however, limited data of foreign establishments have been recorded in regard to fisheries and seaweeds sectors.

\subsection{Tourism and Employment}

Unemployment problem is a major concern of most developing nations; the policy markers propose different measures to help address and eradicate or at least reduce this alarming feature of most economies. Tanzania on the other side puts in place and implements different strategies to boost the economy including the possibility of creating employment. Liberalization of tourism industry is among the initiatives by the Government to address economic problems. The study revealed that $77.8 \%$ of respondents agreed with the idea that tourism industry employs many people in Zanzibar, whilst the remaining $22.2 \%$ object to show that they don't support or they have a concern about employment in the industry. The tourism industry not only provides employment for local Zanzibaris but also other people from within the United Republic of Tanzania are working in Zanzibar's tourism industry. The industry also provides employment to other people from East African countries, for instance Kenya. Some experts from around the world are also hired to provide their services in either hotel restaurants or general management of Hotels or tour operators. The study results show that employees in tourism industry earn more in terms of salary and other benefits compared to other industries. In almost all big hotels on the coastal side, employees get free transport to and from work, and while at work no single coin is spent for food since breakfast, lunch and dinner (for those in night shifts) is provided by employers. In this scenario, $77.8 \%$ of the respondents agreed that foreign investors provide opportunity for better job got their views reflected in the findings. The findings are contradicting with the study conducted by [4], showing the remuneration package in the Government Sector for unskilled and semi-skilled work to be twice that of the private sector.

The analysis of this study also confirms a positive relationship between FDI inflow and employment in tourism industry in particular (table 2). Statistically, correlation coefficient is significant at $\mathrm{P}<0.01$ level, this implies that employment increases with an increase in FDI. This positive correlation between FDI and employment reflects the Government policy of providing a conducive investment climate to encourage more FDIs in order to widen its revenue collection and national development including creation of more jobs. Interestingly, $80 \%$ of the respondents believe that FDI is not only providing employment to many people in Zanzibar but also foreign investors offer better jobs. Majority of FDI inflows in tourism go to hotels and accommodation where a big number of jobs are created. The result is also reflected in FDI report [28] where tourism sector accounted for $54.5 \%$ share of private sectors employment. More importantly, the empirical results, derived from correlation test, suggested that an increase in FDI in the entire sample of Zanzibar leads to a relative increase in employment, an outcome supported, despite considerable gaps in the employment data, by an evaluation of the stylized facts on FDI flows. The impact of FDI on employment is greatest at the beginning and is enhanced when trade policies, absorption and financial development are considered. The findings below supported by [9], show that FDI are positively related to employment creation. [9], points out that FDI will improve competitiveness and, thus, create employment and increase the welfare of the host nation, adding that if FDI is concentrated in labourintensive industries, the increase will be substantial.

The author explains that, FDI can also lead to increased employment amongst local firms as a result of backward or forward linkages so that the direct employment by foreign affiliates may underestimate the total impact. A series of studies have also supported a positive relationship between FDI and employment. [14], for example, reports that FDI is positively affecting the employment growth in foreign-owned firms largely due to their firm characteristics and high survival rates. Similar effects were recorded in privately owned domestic firms as well, possibly due to spillovers. The positive impact of FDI was also evident by [7] for the case of 
Ireland where large FDI inflows were attracted into the export-oriented-foreign firms in the $1990 \mathrm{~s}$ and $63 \%$ of manufacturing employment were provided by these multinational corporations.

Table 2. Correlation between Foreign Direct Investment and Employment.

\begin{tabular}{llll}
\hline & & Foreign Direct Investment & Employment \\
\hline & Pearson Correlation & 1 & $.483^{* *}$ \\
Foreign Direct Investment & Sig. (2-tailed) & & .000 \\
& $\mathrm{~N}$ & 63 & 63 \\
& Pearson Correlation & $.483^{* *}$ & 1 \\
Employment & Sig. (2-tailed) & .000 & 63 \\
& $\mathrm{~N}$ & 63 & 63 \\
\hline
\end{tabular}

**. Correlation is significant at the 0.01 level (2-tailed)

On the contrary, the study contradicts with another study by [25], which reports that there was no causality between FDI inflows and employment [25] for the period of 19702005, whereas it concludes that FDI inflows negatively affected employment in Turkey as the majority of FDI inflows took the form of M\&As rather than Greenfield investment.

\subsection{FDI and Social Development}

The analysis was also conducted to test the relationship between FDI and development of the society. The results reveal correlation test between the two variables which is positive, at $32.9 \%$ as shown in table 3 below. Statistically, a correlation is significant at $\mathrm{P}<0.01$, implying that results agree a positive relationship between foreign investment and the development of the society in Zanzibar. The result is not only reflecting the notion that new investments create new jobs, but also these new investments recognize the value for social responsibility. This was also supported by one of the respondents who commented: "We are proud that villagers are enjoying pure water through our effort to install and operate water pump machine to serve in our hotels' clients and the society; not only that, but we provide support to students normally camping for their final exams". It is the intention of attracting more investment in tourism in many villages that forced the government to boost its budget to allocate fund for infrastructure such as building of roads and bring other important facilities such as electricity and communication to villages. On their side, investors admit the need to support societies surrounding their investment hoping that nothing will end in air, but will gain loyalty and security to the business through the sense of ownership from natives, as some of the interviewees pointed out with the following comment: "Our motto stresses on being 'authentically local'; we are very much trying to train and recruit as many local villagers as we can. We believe that the success of our business is in the hands of a sound society; it doesn't bring a loss to business if a tiny portion of business earnings is set aside for social responsibility".

Table 3. Correlation between FDI and Development of the society.

\begin{tabular}{llll}
\hline & & Foreign Direct Investment & Social Development \\
\hline \multirow{3}{*}{ Foreign Direct Investment } & Pearson Correlation & 1 & $.329^{* *}$ \\
& Sig. (2-tailed) & & .009 \\
& $\mathrm{~N}$ & 63 & 63 \\
\multirow{3}{*}{ Societal Development } & Pearson Correlation & $.329^{* *}$ & 1 \\
& Sig. (2-tailed) & .009 & 63 \\
\hline
\end{tabular}

**. Correlation is significant at the 0.01 level (2-tailed)

In general, tourism sector is perceived as an engine for Zanzibar economy as it contributes to the government collection in terms of licenses and taxes levied on the sector. On an interview, it was observed that tourism is potential for economic development. About $92 \%$ of the respondents disclosed that tourism is a very important economic sector in Zanzibar and it contributes much to employment creation directly and indirectly through multiplier effect, foreign exchange earnings, poverty alleviation and Growth of Domestic Products.

\section{Conclusion and Recommendations}

The study observed that tourism industry attracts many foreign investors through which it provides a significant contribution to the economic development of Zanzibar. Among the benefits of FDI are job creation, poverty reduction through social responsibility such as improvement of infrastructure such as roads, and increasing the rate of government revenue collection. Based on the analysis of the data and the main indicators of Zanzibar's tourism industry between 2009 and 2014, we can state that the increase of FDI in tourism has certainly had an impact on the employment creation in Zanzibar economic growth. According to the study, the impact basically depends on seasonality of tourism which is divided into high and off seasons. In this regard, it was also noted that the industry experiences certain cases of job cut in every aspect of tourism industry during off or low season. FDI provides significant contribution to the Zanzibar economy while meeting their legal and financial obligations 
such as payment statutory taxes. Tourism in Zanzibar plays a crucial role in economic development and poverty reduction; mainly due to introduction and implementation of pro poor tourism in Zanzibar. The favorable effect of the FDI on tourism has pulled up the government effort toward poverty reduction. Thus, the national goal of reducing poverty can be achieved when more effort is put in place. The increase in FDI has been observed particularly in the tourism industry and in the Zanzibar economy as in other developing countries. Therefore, to take advantage of external financial markets, Zanzibar tourism should increase the value of its product significantly and market it effectively. A joint public private partnership can help to enhance economic activity in Zanzibar and help the growth of Zanzibar business and economy. Tourism operators should continue to enhance their product's value and competitiveness through pricediscounting and special offers.

Notwithstanding, the Foreign Direct Investment (FDI) was mentioned as among the main factors that affected the labour market in Zanzibar. The research also confirms some other factors that have a greater impact on Zanzibar's employment that need a close attention such as promoting tourism attraction abroad, balancing tourism and other income based activities, attracting FDI in other sectors of the economy, and emphasizing local efforts in economic growth. In order to have substantial economic growth, policy reforms are required to improve its competitiveness and services. These reforms should be addressed to all existing institutional and structural weaknesses. Immediate reforms are required and such reforms are trade policy and financial reforms. The country has left aside other commodity sectors such as fisheries and seaweeds in which many individuals earn their daily living. When proper policies are kept in place these industries will attract foreign investors and be a supplementary means on both creating employment and contribute towards development.

\section{References}

[1] Abbas, S., and Nishat, M. (2009). The impact of Foreign Direct Investment on Employment opportunities: Panel Data analysis. In; $25^{\text {th }}$ Annual PSDE Conference, $16^{\text {th }}-17^{\text {th }}$ March 2010, Islamabad, Pakistan; pp. 1-14.

[2] Aislabie, C. J., Stanton, P. J. and Tisdell, C. A. (2010). Themes in tourism research: an overview. In; Economics of Tourism. Case Study and Analysis. The Institute of Industrial Economics, NSW, Australia: pp. 1-37.

[3] Alguacil, M. T. Cuadros, A. and Ortos, V. (2004). Foreign direct investment, exports and domestic performance in Mexico: a causality analysis. Economics Letters. 77 (3): pp. 371-376.

[4] Alamki S (2007). Emerging strains in GCC Labor market.

[5] Athukorala W. (2003). the Impact of Foreign Direct Investment for Economic Growth: A Case Study in Sri Lanka. In; 9th International conference on Sri Lanka Studies. 28th 30th November 2003, Matara, Sri Lanka. 92: 21 pp.
[6] Axarloglou, K. and Pournarakis, M. (2007). 'Do All Foreign Direct Investment Inflows Benefit the Local Economy'. World Economy; Vol 30, Issue 3. pp. 424-445.

[7] Barry, F. and Bradley, J. (2007). FDI and Trade: The Irish Host-Country Experience. Economic Journal. 97 (13): pp. 1798-1811.

[8] Craigwell, R. (2006). Foreign Direct Investment and Employment in the English- and Dutch-speaking Caribbean. International Labour Office. Port of Spain: 57pp.

[9] Dunning, J. H. (2012), "The prospects for foreign direct investment in Central and Eastern Europe". 'In'. The Economics of Change in Eastern and Central Europe: Its Impact on International Business. (Edited by Buckley, P. J. and Ghauri, P. N.). Academic Press. London. pp. 1-32.

[10] Ernst, C. (2009), "The FDI-Employment Link in a Globalizing World: The Case of Argentina, Brazil and Mexico." Employment Strategy Papers. 17: pp. 52.

[11] Fazekas, K. and Ozsvald, E. (2011), “ Impacts of FDI Inflows on Labour Markets Differences in Hungary: Stylized Facts and Policy Implications", Economic Restructuring and labour Markets in Accession Countries, Research Project commissioned by EU DG Employment, social Affairs and Equal Opportunities, Contract no, VC/2003/0367.

[12] Forsyth, P. and Dwyer, L. (2010), "Modelling Tourism Jobs: Measuring the Employment Impacts of Inbound Tourism". Occasional Paper. 2: pp. 1-28.

[13] Hymen, S. H. (1960), the international operations of national firms: a study of direct investment. Cambridge University, England. $197 \mathrm{pp}$.

[14] Karlsson, S. Nannan, L. Fredrik, S. Ping, H. (2009), Foreign Firms and Chinese Employment. World Economy. 32 (1): pp. 178-201.

[15] Koldas, T. and Senses F. (2009), Some Salient Features of Recent Turkish FDI Experience with Special Emphasis on Export and Employment Performance. Middle East Technical University Studies in Development. 32 (2): pp. 409-431.

[16] Massoud, N. (2008), Assessing the Employment Effect of FDI Inflows to Egypt: Does the Mode of Entry Matter? In; International Conference on "The Unemployment Crisis in the Arab Countries". 17 $7^{\text {th }}-18^{\text {th }}$ March, 2008. Cairo, Egypt: pp. 121.

[17] Mehtap, H. Derya, G. Ahmet, A. (2007), Can FDI be a Panacea for Unemployment? The Turkish Case. Working paper series. 24: $27 \mathrm{pp}$.

[18] Ndikumana, L. and Verick, S. (2008), The Linkages between FDI and Domestic Investment: Unravelling the Developmental Impact of Foreign Direct Investment in Sub Saharan Africa. IZA Working Paper. 3296: 35 pp.

[19] Onaran, O. (2008), Jobless Growth in the Central and East European Countries: A Country- Specific Panel Data Analysis of the Manufacturing Industry. Eastern European Economics. 46 (4): pp. 90-115.

[20] Pacheco-lopez, (2005). Foreign Direct Investment, Exports and Imports in Mexico. World Economy. 28 (8): pp. 11571172 . 
[21] Pei, N. and Van der Esch, K. (2013). The Impact of FDI on Developing Countries. China \& World Economy. 12 (6): pp. 109-117.

[22] Sekaran, U (2003). Research Methods for Business; A skill Building Approach, $4^{\text {th }}$ Edition. Malloy Lithographing, Inc. Ann Arbor. 466 pp.

[23] Sun, H. (1996). Direct Foreign Investment and Linkage Effects: the Experience of China. Asian Economies. 25 (1): pp. 5-28.

[24] Telfer, D. J. and Wall, D. J. (2000). Strengthening Backward Economic Linkages: Local Food Purchasing by Three Indonesian Hotels. Tourism Geographies. 2 (4): 421-447.
[25] Vergil, H. Ayas, N (2009). ANCTADN 2009, "World Investment Report 2008".

[26] Wond and Tang (2007). Foreign direct investment and services trade: Evidence from Malaysia and Singapore.

[27] World Trade Organization (2005). World Trade Report: Exploring the link between trade, standards and the WTO. WTO publications, Geneva: 377 pp.

[28] ZIPA (2015). Zanzibar Investment Report. Government Press, Zanzibar: $45 \mathrm{pp}$. 